\title{
レーザーオリジナル
}

\section{内部鏡型 $\mathrm{He}-\mathrm{Ne}$-ザーの自己光ガルバノ効果

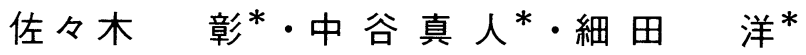

(1990年 8 月27日 受理)

\section{Self-Optogalvanic Effect of Internal-Mirror He-Ne Lasers}

\author{
Akira SASAKI* , Masato NAKAYA * and Hiroshi HOSODA *
}

(Received August 27, 1990)

\begin{abstract}
A self-optogalvanic effect in the laser positive column of internal-mirror He-Ne lasers is investigated both experimentally and theoretically. The effect of laser power fluctuation on the voltage across a laser discharge tube and its dependence on laser currents (3-7 mA) are observed. A general model based on the steady-state solution of rate equations is developed to interpret the measurements. Good agreement between experimental and calculated results is obtained.
\end{abstract}

Key Words : Optogalvanic effect, Self-optogalvanic effect, He-Ne laser, Internal-mirror $\mathrm{He}$-Ne laser.

\section{1.はじめに}

放電中の原子, 分子の光学遷移と共鳴する光 を入射すると放電管中の放電電流あるいは放電 抵抗が入射光強度の変動に伴い変化する現象が 光ガルバノ効果 (OG効果) と呼ばれ, He-Neレー ザーにおいても観測されている ${ }^{1-4)}$ 。この効果 は入射光が放電ガスの定常状態密度あるいはイ オン化の程度に影響を与えるために生じると考 えられている。また， OG効果は原子・分子の 分光および分光分析等にも使用されており, 応 用範囲は広い ${ }^{4-6)}$ 。

$\mathrm{OG}$ 効果はまた $\mathrm{CO}_{2}$ レーザーの周波数安定化 及びレーザー出力変動検出等にも使用されてい $ろ^{7,8)}$ 。これらは $\mathrm{CO}_{2}$ レーザー管の活性レーザー
放電媒体中にレーザー光それ自身によって生じ た自己照射効果であり，本報告ではこのような 効果を自己光ガルバノ効果 (SOG 効果) と呼ぶ。 外部鏡型He-Neレーザーにおいても，自己照射 効果が観測されているが方), 理論的解析は行 なわれていない, また内部鏡型He-Neレーザー においてはまだその効果は観測されていない。 内部鏡型レーザーにおいては放電管とレーザー 反射鏡が一体化しているため，レーザー反射鏡 間距離がレーザー管温度上昇とともに熱膨張 し, 縦モードが移動するためレーザー出力・周 波数が変動する ${ }^{9,10)}$ 。この変動に伴う内部鏡型 He-NeレーザーのSOG効果を測定すると共に, レーザー動作に関係しているHeと Ne原子のエ ネルギー準位及び放電で発生した電子とイオン

* 静岡大学工学部 ( $=432$ 浜松市城北3-5-1)

* Faculty of Engineering, Shizuoka University (Johoku, Hamamatsu 432) 
を考慮したレート方程式を立て，これらの方程 式を定常状態で解き，レーザー出力变化と放電 インピーダンス変化との関係を理論的に解析す るとともに実験結果と比較検討することを目的 とする。

\section{2. 実 験}

本実験において使用した測定系のブロック図

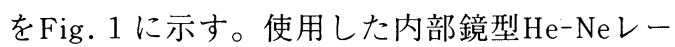
ザー ( $\lambda=633 \mathrm{~nm})$ はUNL-205PS (ウシオ社)で あり，縦モード間隔が $1260 \mathrm{MHz}$ (レーザー反射 鏡間距離 $11.9 \mathrm{~cm})$ であり，ほぼ単一縦モード状 態で発振している。使用したレーザーの放電細 管半径 $(r)$ は $0.475 \mathrm{~mm}, \mathrm{He}$ 分圧 $\left(P_{\mathrm{He}}\right)$ は2.37 Torr, Ne分圧 $\left(P_{\mathrm{Ne}}\right)$ は0.325 Torrであり，全圧 $(P)$ は2.695 Torrである。レーザー発振には自 作の高精度定電流電源を使用した。レーザー放 電電流は可変でき, 電流安定度は $\pm 0.001 \%$ 以 下であった。定電流電源はバラスト抵抗 $(50 \mathrm{k}$ 凤)を介してレーザー管に接続した。レーザー 放電電圧は自作の絶縁型電圧測定器をもちいて 測定し, 放電電圧変動は差動増幅器を使用し基 準電圧值を減算することで測定した。また,レー ザー出力光強度及び変動はシリコンフォトダイ オードを電流一電圧変換器に接続し測定した。

Fig. 2 に使用したレーザーの相対的出力光強度 とレーザー放電電流との関係を示す。Fig. 3 に

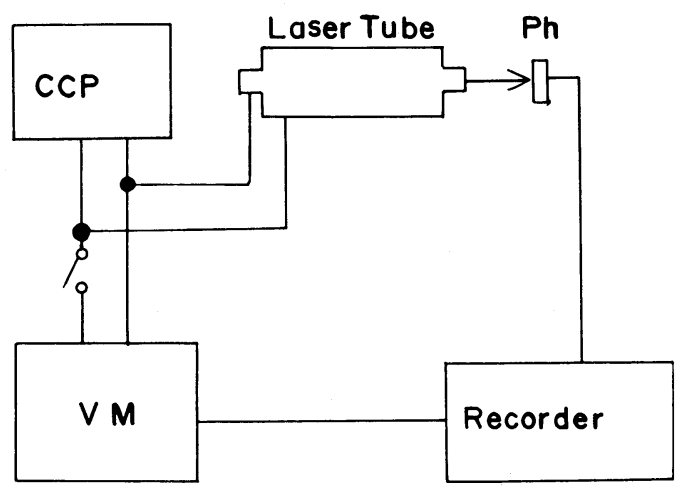

Fig.1 Schematic of the experimental setup of the self-optogalvanic effect. CCP, constant current power supply ; $\mathrm{Ph}$, silicon photodiode ; $\mathrm{VM}$, isolated amplifier.

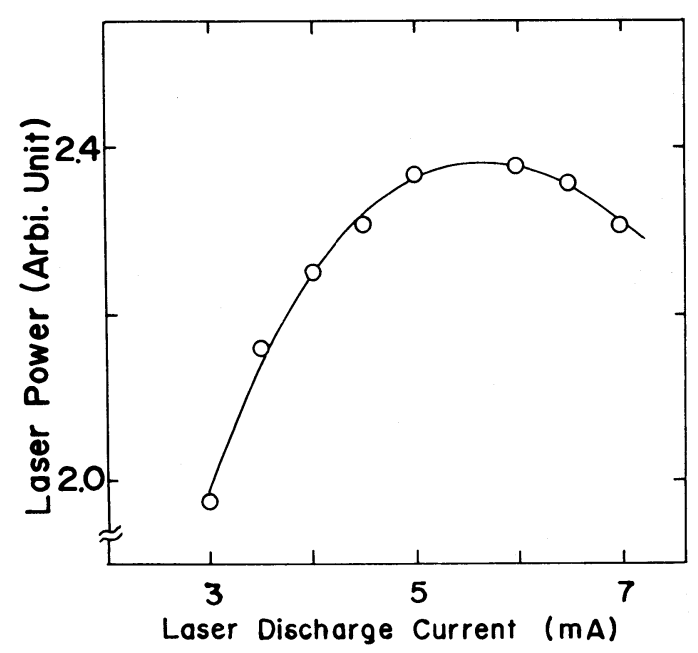

Fig.2 Laser output power as a function of laser discharge current. The solid curve represents theoretical results.

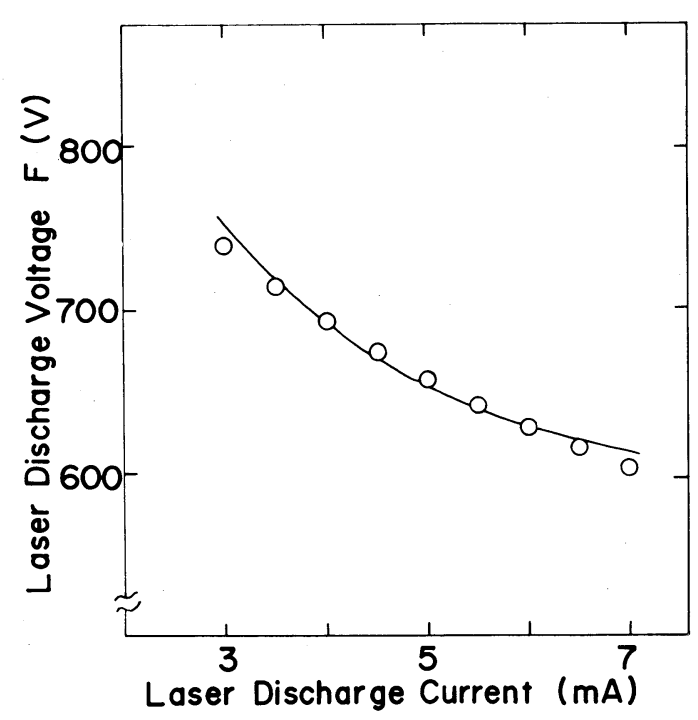

Fig. 3 Laser discharge voltage as a function of laser discharge current. The solid curve represents theoretical results.

レーザー放電電圧とレーザー放電電流との関係 を示す。Fig. 4 にレーザー放電電流 $5 \mathrm{~mA}$ の場 合のレーザー出力光強度及びレーザー放電電圧 変動の時間変化を示す。図に拈いてはレーザー 


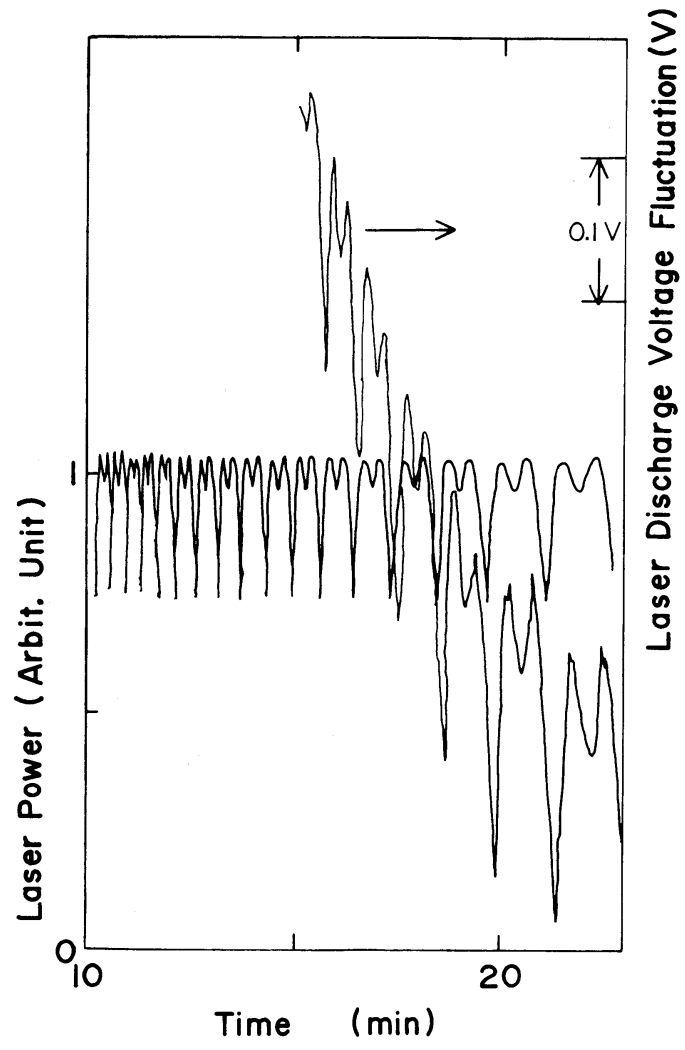

Fig.4 Experimental results of laser discharge voltage and laser output power as a function of time. The laser discharge current is $5 \mathrm{~mA}$.

点灯10分後からの測定結果を示す。レーザーは 主に単一縦モード発振しているため,レーザー 出力光強度にラムディプが観測される。それに 対応して，レーザー放電電圧変動にもその効果 によると考えられるディプが観測される。レー ザー放電電圧変動と時間との関係には 2 成分が あると考えられる。すなわち図からわかるよう に, レーザー出力光強度の長期的わずかな減少 にともない放電電圧が時間とともに減少する長 期的変動に対応する成分と，レーザー管の熱膨 張に伴う縦モード移動のため生じるレーザー出 力光変動 ${ }^{9,10)}$ に対応する放電電圧変動の成分で ある。レーザー共振器長がレーザー波長の半波 長熱膨張するごとにレーザー出力光強度が周期 的に変動するのが後者である。また前者の長期
的変動原因の 1 つはレーザー鏡の熱的に発生す る傾きのため出力が減少したため発生したと考 えられ，後者の原因と異なるため，以下の議論 においては縦モード移動に伴うレーザー光出力 変動及び放電電圧変動を議論する。レーザー放 電電圧変動とレーザー出力光変動との関係は レーザー出力が大きくなるほどレーザー放電電 圧が大きくなる傾向を示す。このようにレー ザー光強度変動と放電電圧変動の間には関連が あり，SOG効果が認められたと考えられる。

Fig. 5 に放電電流 $5 \mathrm{~mA}$ の場合の相対的放電 電圧変化 $(\Delta F / F)$ と相対的レーザー光強度変 動 $\left(\Delta n_{\mathrm{f}} / n_{\mathrm{f}}\right)$ との比とレーザー点灯後の時間と の関係を示す。時間と共に值が一定でなく変化 するのは，レーザー管内の温度が時間と共に上 昇するためその効果が表れたと考えられる。約 20分後には測定值がほぼ一定值となるのはレー ザー放電管がほぼ熱的定常状態に達しているた めと考えられる。Fig. 6 に相対的放電電圧变化 $(\Delta F / F)$ と相対的レーザー光強度变動 $\left(\Delta n_{\mathrm{f}}\right)$ $\left.n_{\mathrm{f}}\right)$ との比と放電電流との関係を示す。○印が 実験值であり, 放電開始約20分後の值で示して ある。

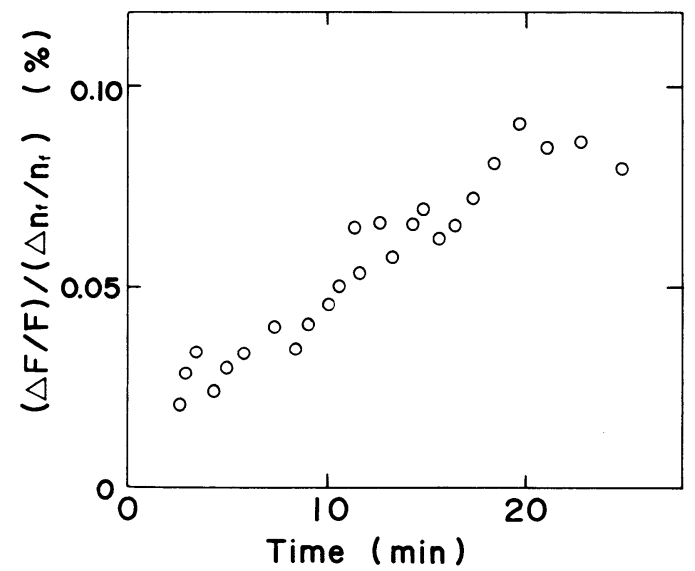

Fig.5 $(\Delta F / F) /\left(\Delta n_{\mathrm{f}} / n_{\mathrm{f}}\right)$ as a function of time. The laser discharge current is $5 \mathrm{~mA}$. 


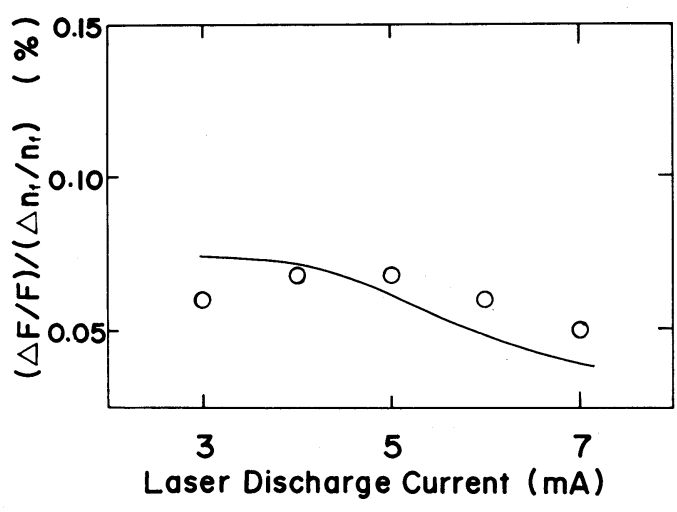

Fig.6 $(\Delta F / F) /\left(\Delta n_{\mathrm{f}} / n_{\mathrm{f}}\right)$ as a function of laser discharge current. The solid curve represents theoretical results.

\section{3. 理論的解析}

内部鏡型 $\mathrm{He}$ - NeレーザーのSOG効果を理論的 に解析するため，Fig. 7 に示す簡略化したエネ ルギー準位の場合について考える。四のように $\mathrm{He}$ の $2^{1} \mathrm{~S}$ 及びNeの $1 \mathrm{~s}, 2 \mathrm{p}_{4}, 3 \mathrm{~s}_{2}$ 準位 (Paschen表示 以下同じ)についてのみ考える。使用したパラ メーターの定義をTable I に示す。 $n_{\mathrm{e}}, n_{\mathrm{f}}$ およ びn $n_{i} に$ 対するレート方程式は以下で与えられ る。

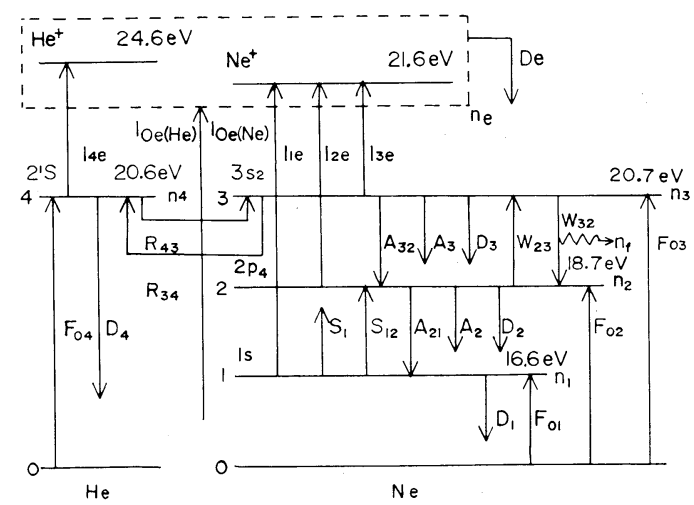

Fig.7 Simplified energy-level diagram for a $\mathrm{He}^{-\mathrm{Ne}}$ laser. The main processes of electron impact excitation, radiative decay, and collisional energy transfer are shematically represented.
Table I Definition of parameters

\begin{tabular}{|c|c|}
\hline パラメーター & 定 義 \\
\hline$n_{\mathrm{e}}\left(\mathrm{cm}^{-3}\right)$ & 電子密度 \\
\hline$n_{\mathrm{f}}\left(\mathrm{cm}^{-3}\right)$ & 光子密度 \\
\hline$n_{i}\left(\mathrm{~cm}^{-3}\right)$ & $i$ 準位の密度 \\
\hline$N_{\mathrm{He}}\left(\mathrm{cm}^{-3}\right)$ & Heの密度 \\
\hline$N_{\mathrm{Ne}}\left(\mathrm{cm}^{-3}\right)$ & $\mathrm{Ne}$ の密度 \\
\hline$A_{i j}\left(s^{-1}\right)$ & $\begin{array}{l}i \text { 準位から } j \text { 準位への自然放出 } \\
\text { 確率 }\end{array}$ \\
\hline$A_{i}\left(\mathrm{~s}^{-1}\right)$ & $\begin{array}{l}i \text { 準位から } j \text { 準位以外への自然 } \\
\text { 放出確率 }\end{array}$ \\
\hline$D_{i}\left(\mathrm{~s}^{-1}\right)$ & $i$ 準位からの脱励起確率 \\
\hline$D_{\mathrm{e}}\left(\mathrm{s}^{-1}\right)$ & 拡散係数 \\
\hline$F_{0 i}\left(\mathrm{~s}^{-1}\right)$ & $\begin{array}{l}\text { 基底状態から } i \text { 準位への直接励 } \\
\text { 起確率 }\end{array}$ \\
\hline$I_{i \mathrm{e}}\left(\mathrm{s}^{-1}\right)$ & $i$ 準位からのイオン化確率 \\
\hline$R_{i j}\left(\mathrm{~s}^{-1}\right)$ & $\begin{array}{l}i \text { 準位から } j \text { 準位へのエネル } \\
\text { ギー遷 移確率 }\end{array}$ \\
\hline$S_{i j}\left(\mathrm{~s}^{-1}\right)$ & $\begin{array}{l}i \text { 準位から } j \text { 準位への段階的励 } \\
\text { 起確率 }\end{array}$ \\
\hline$S_{i}\left(\mathrm{~s}^{-1}\right)$ & $\begin{array}{l}i \text { 準位から } j \text { 準位以外への段階 } \\
\text { 的励起確率 }\end{array}$ \\
\hline$W_{23}\left(\mathrm{~s}^{-1}\right)$ & 誘導吸収確率 \\
\hline$W_{32}\left(\mathrm{~s}^{-1}\right)$ & 誘導放出確率 \\
\hline$q\left(\mathrm{~s}^{-1}\right)$ & 光子損失 \\
\hline$D_{\mathrm{a}}\left(\mathrm{cm}^{2} / \mathrm{s}\right)$ & 両極性拡散係数 \\
\hline$\mu_{\mathrm{e}}\left(\mathrm{cm}^{2} /(\mathrm{s} \cdot \mathrm{V})\right)$ & 電子移動度 \\
\hline$D^{\prime}(\mathrm{V})$ & $D,=D_{\mathrm{a}} / \mu_{\mathrm{e}}$ \\
\hline$r(\mathrm{~cm})$ & 放電管内径半径 \\
\hline$F(\mathrm{~V})$ & レーザー管放電電圧 \\
\hline$L_{\mathrm{d}}(\mathrm{cm})$ & 放電長 ～～～～～ \\
\hline$E(\mathrm{~V} / \mathrm{cm})$ & $E=F / L_{\mathrm{d}}$ \\
\hline$v_{\mathrm{e}}(\mathrm{cm} / \mathrm{s})$ & 電子速度 \\
\hline
\end{tabular}

$$
\begin{aligned}
& \mathrm{d} n_{\mathrm{e}} / \mathrm{d} t=I_{\mathrm{Oe}(\mathrm{He})} N_{\mathrm{He}}+I_{\mathrm{Oe}}\left(N_{\mathrm{e}}\right) N_{\mathrm{Ne}}+I_{1 \mathrm{e}} n_{1} \\
& +I_{2 \mathrm{e}} n_{2}+I_{3 \mathrm{e}} n_{3}+I_{4 \mathrm{e}} n_{4}-D_{e} n_{\mathrm{e}} \\
& \mathrm{d} n_{\mathrm{f}} / \mathrm{d} t=W_{32} n_{3}-W_{23} n_{2}+A_{32} n_{3}-q n_{3} \\
& \mathrm{~d} n_{1} / \mathrm{d} t=F_{01} N_{\mathrm{Ne}}+A_{21} n_{2}+\left(D_{1}+I_{1 \mathrm{e}}+S_{1}\right. \\
& \left.\quad+S_{12}\right) n_{1} \\
& \mathrm{~d} n_{2} / \mathrm{d} t=F_{02} N_{\mathrm{Ne}}+S_{12} n_{1}+\left(A_{32}+W_{32}\right) n_{3} \\
& \quad-\left(D_{2}+A_{2}+A_{21}+I_{2 \mathrm{e}}+W_{23}\right) n_{2} \\
& \mathrm{~d} n_{3} / \mathrm{d} t=F_{03} N_{\mathrm{Ne}}+W_{23} n_{2}+R_{43} n_{4} \\
& -\left(D_{3}+A_{3}+A_{32}+I_{3 \mathrm{e}}+R_{34}+W_{32}\right) n_{3}
\end{aligned}
$$


$\mathrm{d} n_{4} / \mathrm{d} t=F_{04} N_{\mathrm{He}}+R_{34} n_{3}-\left(D_{4}+I_{4 \mathrm{e}}+R_{43}\right) n_{4}$

レート方程式 (3)- (6) を定常状態 $\mathrm{d} n_{i} / \mathrm{d} t=0$ と おいて解くと, $n_{i}$ は

$$
\begin{aligned}
& n_{1}=\left(\alpha_{0}+\alpha_{2} n_{2}\right) / \alpha_{1} \\
& n_{2}=N_{2} / N_{0} \\
& n_{3}=N_{3} / N_{0} \\
& n_{4}=\left(\delta_{0}+\delta_{3} n_{3}\right) / \delta_{4}
\end{aligned}
$$

となる。ここで

$$
\begin{aligned}
\alpha_{0}= & F_{01} N_{\mathrm{Ne}}, \quad \alpha_{1}=D_{1}+I_{1 \mathrm{e}}+S_{1}+S_{12}, \\
& \alpha_{2}=A_{21} \\
\beta_{0}= & F_{02} N_{\mathrm{Ne}}, \quad \beta_{1}=S_{12}, \\
\beta_{2}= & D_{2}+A_{2}+A_{21}+I_{2 \mathrm{e}}+W_{23}, \\
& \beta_{3}=A_{32}+W_{32} \\
\gamma_{0}= & F_{03} N_{\mathrm{Ne}}, \gamma_{2}=W_{32}, \\
\gamma_{3}= & D_{3}+A_{3}+A_{32}+I_{3 \mathrm{e}}+R_{34}+W_{32}, \gamma_{4}=R_{43} \\
\delta_{0}= & F_{04} N_{\mathrm{He}}, \quad \delta_{3}=R_{34}, \quad \delta_{4}=D_{4}+I_{4 \mathrm{e}}+R_{43}
\end{aligned}
$$

および

$$
\begin{aligned}
N_{2} & =\left(\alpha_{0} \beta_{1}+\alpha_{1} \beta_{0}\right)\left(\gamma_{3} \delta_{4}-\gamma_{4} \delta_{3}\right) \\
& +\alpha_{1} \beta_{3}\left(\gamma_{0} \delta_{4}+\gamma_{0} \delta_{4}\right) \\
N_{3} & =\left(\alpha_{0} \beta_{1}+\alpha_{1} \beta_{0}\right) \gamma_{2} \delta_{4} \\
& +\left(\alpha_{1} \beta_{2}-\alpha_{2} \beta_{1}\right)\left(\gamma_{0} \delta_{4}+\gamma_{4} \delta_{0}\right) \\
N_{0} & =\left(\alpha_{1} \beta_{2}-\alpha_{2} \beta_{1}\right)\left(\gamma_{3} \delta_{4}-\gamma_{4} \delta_{3}\right) \\
& -\alpha_{1} \beta_{3} \gamma_{2} \delta_{4}
\end{aligned}
$$

である。

定常状態において $n_{\mathrm{f}}$ は (2) 式より

$$
n_{\mathrm{f}}=\left(W_{32} n_{3}-W_{23} n_{2}\right) / q
$$

\section{と表される。}

電子密度 $n_{\mathrm{e}}$ に関するレート方程式を定常状 態で解き, 拡散係数について变形し, $i_{i \mathrm{e}}=I_{i \mathrm{e}}$ $/ n_{\mathrm{e}}$ と置くと

$$
\begin{aligned}
D_{\mathrm{e}}= & i_{0_{\mathrm{e}}(\mathrm{He})} N_{\mathrm{He}}+i_{\mathrm{Oe}_{\mathrm{e}}(\mathrm{Ne})} N_{\mathrm{Ne}}+i_{1 \mathrm{e}} n_{1}+i_{2 \mathrm{e}} n_{2} \\
& +i_{3 \mathrm{e}} n_{3}+i_{4 \mathrm{e}} n_{4}
\end{aligned}
$$

となる。またD $\mathrm{e}$

$$
D_{\mathrm{e}}=D^{\prime}\left\{(2.4 / r)^{2}+\left(\pi / L_{\mathrm{d}}^{2}\right\} v_{\mathrm{e}} / E\right.
$$

と表される ${ }^{8)}$ 。またこの式よりレーザー管の放 電電圧 $F$ を求めると

$$
F=L_{d} D^{\prime}\left\{(2.4 / r)^{2}+\left(\pi / L_{\mathrm{d}}{ }^{2}\right\} v_{\mathrm{e}} / D_{\mathrm{e}}\right.
$$

となる。

レーザー管の放電電気抵抗 $R$ は放電電流を $I$ とすると, $R=F / I=L_{\mathrm{d}} E / I$ であり, 定常状態

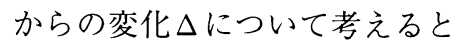

$$
\Delta R / R=\Delta F / F-\Delta I / I=\Delta E / E-\Delta I / I
$$

であるが,レーザー電源に定電流電源を用いて いるため $\Delta I=0$ となり, (14) 式は $\Delta R / R=\Delta F$ $/ F=\Delta E / E$ となり，(13)そして (12)式より $\Delta$ $E / E$ は

$$
\begin{aligned}
\frac{\Delta E}{E} & =\frac{\Delta D^{\prime}}{D^{\prime}}+\frac{\Delta v_{\mathrm{e}}}{v_{\mathrm{e}}} \\
& -\sum_{i=1}^{4}\left\{\frac{i_{i \mathrm{e}} n_{i}}{D_{\mathrm{e}}}\left(\frac{\Delta i_{i \mathrm{e}}}{i_{i \mathrm{e}}}+\frac{\Delta n_{i}}{n_{i}}\right)\right\}
\end{aligned}
$$

と表される。 $\Delta D^{\prime} / D^{\prime}$ 及び $\Delta I_{i} / I_{i} \mathrm{e}$ は $\Delta v_{\mathrm{e}} / v_{\mathrm{e}}$ と同じオーダーであると考えられるので，(15） 式は

$$
\frac{\Delta E}{E}=-\sum_{i=1}^{4}\left\{\frac{i_{i \mathrm{e}} n_{i}}{D_{\mathrm{e}}} \cdot \frac{\Delta n_{i}}{n_{i}}\right\}
$$

と近似できる。(7)-(10) 式と (16) 式より

$$
\begin{aligned}
& \left(\frac{\Delta F}{F}\right) /\left(\frac{\Delta n_{\mathrm{f}}}{n_{\mathrm{f}}}\right)= \\
& -\left\{\frac{i_{1 \mathrm{e} n_{1}}}{D_{\mathrm{e}}} \cdot \frac{\alpha_{2^{n_{2}}}}{\alpha_{0}+\alpha_{2^{n_{2}}}} \cdot\left(\frac{M_{2}}{N_{2}}-\frac{M_{0}}{N_{0}}\right)\right. \\
& +\frac{i_{2 \mathrm{e}} n_{2}}{D_{\mathrm{e}}} \cdot\left(\frac{M_{2}}{N_{2}}-\frac{M_{0}}{N_{0}}\right) \\
& +\frac{i_{3 \mathrm{e}} n_{3}}{D_{\mathrm{e}}} \cdot\left(\frac{M_{3}}{N_{3}}-\frac{M_{0}}{N_{0}}\right) \\
& \left.+\frac{i_{4 \mathrm{e}} n_{4}}{D_{\mathrm{e}}} \cdot \frac{\delta_{3} n_{3}}{\delta_{0}+\delta_{3} n_{3}} \cdot\left(\frac{M_{3}}{N_{3}}-\frac{M_{0}}{N_{0}}\right)\right\}
\end{aligned}
$$

となる。レーザー出力光強度は $n_{\mathrm{f}}$ に比例する と考えられるため, レーザー光強度変化と放電 
電圧変化との関係が導かれたことになる。ここ で

$$
\begin{aligned}
& M_{2}=W_{32}\left\{\left(\alpha_{0} \beta_{1}+\alpha_{1} \beta_{0}\right) \delta_{4}\right. \\
& \left.\quad+\alpha_{1}\left(\gamma_{0} \delta_{4}+\gamma_{4} \delta_{0}\right)\right\} \\
& M_{3}=W_{23}\left\{\left(\alpha_{0} \beta_{1}+\alpha_{1} \beta_{0}\right) \delta_{4}\right. \\
& \left.\quad+\alpha_{1}\left(\gamma_{0} \delta_{4}+\gamma_{4} \delta_{0}\right)\right\} \\
& \quad \\
& M_{0}=W_{23} \alpha_{1}\left(\gamma_{3} \delta_{4}-\gamma_{4} \delta_{3}-\beta_{3} \delta_{4}\right) \\
& \quad+W_{32} \delta_{4}\left(\alpha_{1} \beta_{2}-\alpha_{2} \beta_{1}-\alpha_{1} \gamma_{2}\right)
\end{aligned}
$$

である。

Fig. 2 に○印でレーザー出力光強度と放電電 流との実験結果を示したが, 図において実線が (11)，(8)，(9)式およびTable IIのパラメーター から計算した理論值であり, 実験結果とほぼ一 致する。Fig. 3 に○印でレーザー放電電圧と放
電電流との実験結果を示したが, 図において実 線が(13) 式より計算した理論值であり，実験 結果とほぼ一致する。Fig. 6 に $(\Delta F / F) /$ $\left(\Delta n_{\mathrm{f}} / n_{\mathrm{f}}\right)$ と放電電流の関係の実験結果を○印 で示したが, この関係の理論值を(17)式より計 算する。計算に使用したパラメータをTable II に示す。表において $n_{\mathrm{e}} v_{\mathrm{e}}$ の值は参考文献 ${ }^{12)} に$ したがって計算した。 $n_{\mathrm{e}}$ はレーザー放電電流 $I$ に比例する ${ }^{12)}$ ，また表に示したように他のパ ラメータもIに関係するものもあり， $(\Delta F / F)$ $/\left(\Delta n_{\mathrm{f}} / n_{\mathrm{f}}\right)$ とIの関係を簡単な理論式で示す のは難しい。また，この表において $v_{\mathrm{He}-\mathrm{Ne}}$ は $\mathrm{He}$ と $\mathrm{Ne}$ の相対速度である。Fig. 6 に実線で示 したのが理論值であり, 理論値は実験結果と ほぼ一致している。また，理論計算における $(\Delta F / F) /\left(\Delta n_{\mathrm{f}} / n_{\mathrm{f}}\right)$ の負号は正であり, 実験 結果の負号と一致している。

Table II Values of rate coefficients

\begin{tabular}{l|c|c}
\hline \multicolumn{1}{c|}{ Coefficients } & Value & Ref. \\
\hline$A_{21}\left(\mathrm{~s}^{-1}\right)$ & $5.24 \times 10^{7}$ & 11 \\
$A_{32}\left(\mathrm{~s}^{-1}\right)$ & $1.3 \times 10^{7}$ & 11 \\
$D_{1}\left(\mathrm{~s}^{-1}\right)$ & $7.6 \times 10^{5} /\left(P r^{2}\right)+5.9 \times 10^{3} P$ & 11 \\
$D_{2}+A_{2}\left(\mathrm{~s}^{-1}\right)$ & $1.64 \times 10^{7}\left[1+0.4 P+0.07 I(r P)^{1 / 4} / r^{2}\right]$ & 12,13 \\
$D_{3}+A_{3}\left(\mathrm{~s}^{-1}\right)$ & $1.41 \times 10^{7}\left[1+0.4 P+0.22 I(r P)^{1 / 4} / r^{2}\right]$ & 12,13 \\
$D_{4}\left(\mathrm{~s}^{-1}\right)$ & $440\left[(2.4 / r)^{2}+(\pi / L)^{2}\right] / P_{\mathrm{He}}$ & 11 \\
$F_{01}\left(\mathrm{~s}^{-1}\right)$ & $3.0 \times 10^{-18} n_{\mathrm{e}} v_{\mathrm{e}}$ & 12 \\
$F_{02}\left(\mathrm{~s}^{-1}\right)$ & $3.2 \times 10^{-19} n_{\mathrm{e}} v_{\mathrm{e}}$ & 12 \\
$F_{03}\left(\mathrm{~s}^{-1}\right)$ & $5.0 \times 10^{-19} n_{\mathrm{e}} v_{\mathrm{e}}$ & 12 \\
$F_{04}\left(\mathrm{~s}^{-1}\right)$ & $3.3 \times 10^{-19} n_{\mathrm{e}} v_{\mathrm{e}}$ & 12 \\
$I_{1 \mathrm{e}}\left(\mathrm{s}^{-1}\right)$ & $2.1 \times 10^{-15} n_{\mathrm{e}} v_{\mathrm{e}}$ & \\
$I_{2 \mathrm{e}}\left(\mathrm{s}^{-1}\right)$ & $1.0 \times 10^{-15} n_{\mathrm{e}} v_{\mathrm{e}}$ & \\
$I_{3 \mathrm{e}}\left(\mathrm{s}^{-1}\right)$ & $3.0 \times 10^{-15} n_{\mathrm{e}} v_{\mathrm{e}}$ & 11 \\
$I_{4 \mathrm{e}}\left(\mathrm{s}^{-1}\right)$ & $2.6 \times 10^{-15} n_{\mathrm{e}} v_{\mathrm{e}}$ & 15 \\
$R_{34}\left(\mathrm{~s}^{-1}\right)$ & $2.53 \times 10^{-10} N_{\mathrm{He}}$ & 14 \\
$R_{43}\left(\mathrm{~s}^{-1}\right)$ & $11.5 \times 10^{-16} \exp \left(-E_{\mathrm{a}} / k T\right) N_{\mathrm{He}} v_{\mathrm{He}-N \mathrm{e}}$ & 14 \\
& $\left(E_{\mathrm{a}}=0.034 \mathrm{eV}\right)$ & 14 \\
$S_{1}\left(\mathrm{~s}^{-1}\right)$ & $1.21 \times 10^{-14} n_{\mathrm{e}} v_{\mathrm{e}}$ & \\
$S_{12}\left(\mathrm{~s}^{-1}\right)$ & $2.1 \times 10^{-15} n_{\mathrm{e}} v_{\mathrm{e}}$ & \\
$D^{\prime}(\mathrm{V})$ & $k T_{\mathrm{e}} / e=1.1605 \times 10^{4}(10.3-0.075 I) k / e$ & \\
\hline & & \\
\hline
\end{tabular}




\section{4.まとめ}

定電流電源で駆動した内部鏡型 He-Neレー ザーの出力光変動に伴うレーザー放電電圧変動 が測定された。これには 2 成分あり，レーザー 鏡の熱的傾きに伴う成分と，縦モード移動に伴 うレーザー出力変動による成分である。後者は

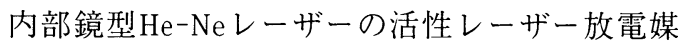
体中にレーザー光それ自身によって生じる自己 照射効果すなわち自己ガルバノ効果であると考 えられる。また，相対的レーザー光強度変化と 相対的放電電圧变化の関係をレート方程式によ り解析的に求め，この結果から計算した值を実 験結果と比較し，両者の間に良い一致を得た。

放電電圧変動の時間的変化における形状と レーザー光強度変動の時間的変化における形状 の間に相関関係があることがわかったため、こ れらの実験結果を応用すると $\mathrm{CO}_{2}$ レーザーで行 なわれているレーザー安定化法と同じように， 単一モード発振内部鏡型He-Neレーザーの自己 ガルバノ効果のラムディプの位置に対応する位 置を利用した安定化法が可能であると考えられ る。

最後に本研究にあたり種々ご協力いただいた 深谷次助氏に感謝いたします。

\section{参 考 文 献}

1) G. Schiffner and F. Seifert : Proc. IEEE 53 (1965) 1965.

2) A. Garscadden and S. L. Adams : Proc. IEEE 54 (1966) 427.

3) D. Apostol, C. Blanaru, A. Ionescu, Gh. Popescu, I. Iovit Popescu and V. Vasiliu : Rev .. Roum. Phys. 27 (1982) 581.

4）鈴木：分光研究 32 (1983) 367.

5）関根, 和田, 廣瀬：レーザー研究 17 (1989) 558.

6) B. Barbieri and N. Beverini : Rev. Mod. Phys. 62 (1990) 603.

7) M. L. Skolnick : IEEE J. Quantum Electron. QE-26 (1970) 139.

8) A. L. Scholtz and G. Schiffner: Appl. Phys. 4 (1980) 407.

9）佐々木，石川：レーザー研究 11 (1983) 754 .

10）佐々木, 石切山, 堀田：レーザー研究 17 (1989) 58.

11) B. E. Cherrington: Gaseous Electronics and Gas Laser (Pergamon Press, 1979) p. 180.

12) T. Sakurai : Jpn. J. Appl. Phys. 11 (1972) 1826.

13) J. T. Verdeyen : Laser Electronics (Prentice Hall, 1982) p. 268.

14) I. M. Beterov and V. P. Chebotaev : Opt. Spectrosc. 22 (1967) 467.

15) C. S. Willett : Introduction to Gas Lasers : Popula tion Inversion Mechanisms (Pergamon Press, 1974) p.38. 